\title{
Throat Carcinoma
}

National Cancer Institute

\section{Source}

National Cancer Institute. Throat Carcinoma. NCI Thesaurus. Code C35506.

Carcinoma, predominantly squamous cell, arising from epithelial cells of the larynx or pharynx. 